\title{
New Treatment Strategies in the Treatment of Juvenile Idiopathic Arthritis
}

\author{
Juvenil İdiopatik Artrit Tedavisinde Yeni Tedavi Yöntemleri
}

\author{
İbrahim GÖKÇE, Erkan DEMİRKAYA \\ Department of Pediatric Nephrology and Rheumatology, Gülhane Military Medical School, Ankara, Turkey
}

Juvenile idiopathic arthritis (JIA) is the most common chronic rheumatic disease in childhood with an incidence of $10-19 / 100.000$ children below the age of 16 years, and it is also one of the major causes of acquired disability and impairment of quality of life in childhood. Early and aggressive control of arthritis is essential to prevent long-term disability. Methotrexate (MTX) provides clinical benefits in JIA with an acceptable profile of toxic effects. Nevertheless, in many cases, inefficacy, especially in patients with polyarticular and systemic-onset form of JIA (SOJIA) or intolerance to MTX, has led investigators to try other therapeutic options. Biologic agents have been designed to target key cytokines implicated in JIA including tumor necrosis factor-a (TNF-a), Interleukin-1 (IL-1), IL-6 as well as signaling molecules involved in the regulation of T-cell and B-cell lympocyte responses. Up to now, the U.S. Food and Drug Administration (FDA) has approved three biologic agents for use in moderate to severe polyarticular JIA: etanercept, adalimumab and abatacept. In general, TNF- $\alpha$ inhibitors are more beneficial for children with polyarticular disease, and the biological agents that target IL-1 and IL- 6 activity appear to be successful also in treating patients with SOJIA. The T-cell costimulation modulator, abatacept, was shown to be effective for the treatment of patients with moderate to severe polyarticular JIA. Autologous stem cell transplantation has also been used in patients with refractory JIA; however, the procedure carries the risk of treatment-related high morbidity and mortality. The purpose of this review is to summarise the recent advances in the treatment of JIA.

Key words: IL-1 inhibitors; juvenile idiopathic arthritis; leflunomide; rituximab; thalidomide; TNF-a inhibitors.

Juvenile idiopathic arthritis (JIA) is the most common chronic rheumatic disease in childhood with an incidence of 10-19/100.000 children below the age of 16
Juvenil idiyopatik artrit (JiA), 16 yaş altı çocuklarda 10-19/100.000 düzeyinde bir insidansla çocukluk çağının en yaygın kronik romatizmal hastalığıdır ve aynı zamanda, bu yaş grubunda edinilmiş fonksiyon yetersizliklerinin ve hayat kalitesinde bozulmanın önemli nedenlerindendir. Erken ve agresif artrit tedavisi kalıcı fonksiyon yetersizliğini önlemede önemlidir. Metotreksat (MTX) JiA'da kabul edilebilir bir toksik etki profiliyle faydalar sağlamaktadır. Bununla beraber MTX'in özellikle poliartiküler ve sistemik başlangıçlı JiંA hastalarında etkili olmaması ve MTX intoleransı araştırmacıları diğer tedavi seçeneklerini denemeye yöneltmiştir. Biyolojik ajanlar JiA patogenezinde sorumlu tutulan interlökin-1 (IL-1), İL-6 ve yanı sıra tümör nekrozis faktör-a (TNF-a) gibi kilit sitokinleri ve $\mathrm{T}$ ve $\mathrm{B}$ lenfosit yanıtının düzenlenmesinde rol alan sinyal moleküllerini hedef alır. Amerikan Gıda ve İlaç Dairesi (FDA) şimdiye kadar orta seviyeli ila ciddi poliartiküler JiA'da kullanılmak üzere üç biyolojik ajana onay vermiştir. Bu ajanlar etanersept, adalimumab ve abataseptir. Genel olarak TNF-a inhibitörleri poliartiküler hastalığı olan çocuklarda daha faydalıdır ve IL-1 ve IL-6 aktivitesini hedef alan biyolojik ajanlar sistemik başlangıçlı JiA'lı hastalarda da başarılı gibi görünmektedir. T hücresi ko-stimülasyon düzenleyicisi abataseptin orta dereceli ila şiddetli poliartiküler JiA'lı hastaların tedavisinde etkiliolduğu gösterilmiştir. Dirençli JiA hastalarında otolog kök hücre nakli de kullanılmıştır ancak bu işlem tedaviyle ilişkili yüksek bir morbidite ve mortalite riski taşımaktadır. Bu derlemede JiA tedavisindeki son ilerlemelerin özetlenmesi amaçlanmıştır.

Anahtar sözcükler: IL-1 inhibitörleri; juvenil idiyopatik artrit; leflunomid; ritüksimab; talidomid; TNF- a inhibitörleri.

years, and it is also a major cause of acquired disability and impairment of quality of life in childhood. ${ }^{[1-5]}$ The term JIA, like its predecessors juvenile rheumatoid 
arthritis and juvenile chronic arthritis, is an umbrella term for clinical patterns of arthritis in children. ${ }^{[6]}$ By definition JIA encompasses a group of clinically heterogenous arthritides that begin prior to age 16 years, are of unknown cause,and present with joint pain, stiffness and swelling that persists for longer than six weeks. ${ }^{[1,7]}$ According to the International League of Associations for Rheumatology (ILAR) classification, JIA is subdivided into seven categories which are different from each other and from adult rheumatoid arthritis (RA). ${ }^{[8,9]}$ The ILAR classification is based on the number of joints affected, the presence or absence of specific serologic findings and systemic manifestations as outlined in table 1.

Without appropriate treatment, JIA may result in devastating consequences. Children may experience permanent disability from joint destruction, growth deformities or blindness. In the case of the systemiconset form of JIA (SOJIA), untreated disease may even result in multiple organ failure and death. ${ }^{[7]}$ Although the outcome for children who have JIA has improved in recent years, it is still less than ideal. ${ }^{[10]}$ Traditionally, the overall prognosis has been thought to be good with up to $60 \%$ of cases entering remission before adulthood, ${ }^{[5,10]}$ but newer studies have not been performed to address this issue. Various studies have shown that $25 \%$ to $70 \%$ of children with JIA will still have ongoing, active disease 10 years after onset ${ }^{[10,11]}$ and $\leq 35 \%$ of patients, regardless of the category of JIA, demonstrated a state of disease inactivity of 12 months or longer while off their medication regimen. ${ }^{[12]}$ These studies indicate that many patients diagnosed with JIA will be exposed to extended periods of medication throughout their lifetimes.

Conventional therapy consists of disease-modifying antirheumatic drugs (DMARDs), such as methotrexate (MTX), as the most common first-line DMARD and non-steroidal anti-inflammatory drugs (NSAIDs), with the avoidance of systemic corticosteroids. More recently, intra-articular corticosteroid injections have been included in the treatment approach, especially in patients with oligoarthritis. Only MTX has proven to be effective and safe in large controlled trials. ${ }^{[13]}$ Nevertheless, in many cases, inefficacy, especially in patients with polyarticular and SOJIA or intolerance to MTX, has led investigators to try other treatment regimens. Prior to the era of biologicals, more than 25\% of polyarticular and nearly $50 \%$ of systemic patients with JIA at five years after onset had functional limitations, and two-thirds had radiographically evident damage. ${ }^{[14]}$ Because none of the available drugs has curative potential, the primary therapeutic goals are to control symptoms, to normalize joint function and to avoid long-term joint damage. ${ }^{[15]}$ The approach to treatment depends on the assessment of individual needs and the disease subtype. Other comorbidities,

Table 1. Classification of juvenile idiopathic arthritis

\begin{tabular}{|c|c|}
\hline Category & Characteristics \\
\hline Systemic onset & $\begin{array}{l}\text { Arthritis in one or more joints, two weeks of fever, plus one or more of rash, lymphadenopathy, } \\
\text { hepatosplenomegaly }\end{array}$ \\
\hline Oligoarthritis & $\begin{array}{l}\text { Arthritis affecting one to four joints for the first six months of disease. After the first six months; } \\
\text { Persistent oligoarthritis: affecting four or fewer joints throughout the disease course } \\
\text { Extended oligoarthritis: affecting more than four joints after six months of disease }\end{array}$ \\
\hline $\begin{array}{l}\text { Polyarthritis, } \\
\text { Rheumatoid factor }(-)\end{array}$ & $\begin{array}{l}\text { Arthritis affecting five or more joints during the first six months of the disease } \\
\text { Rheumatoid factor negative }\end{array}$ \\
\hline $\begin{array}{l}\text { Polyarthritis, } \\
\text { Rheumatoid factor }(+)\end{array}$ & $\begin{array}{l}\text { Arthritis affecting five or more joints during the six months of the disease } \\
\text { Rheumatoid factor positive two or more times, at least three months apart }\end{array}$ \\
\hline Psoriatic arthritis & $\begin{array}{l}\text { Arthritis plus psoriasis or } \\
\text { Arthritis plus two of the following: dactylitis, nail pitting or onycholysis, psoriasis in a } \\
\text { first-degree relative }\end{array}$ \\
\hline Enthesitis-related arthritis & $\begin{array}{l}\text { Arthritis and enthesitis or } \\
\text { Arthritis or enthesitis plus two of the following: sacroiliac joint involvement, HLA-B27 } \\
\text { positive, arthritis in a male }>6 \text { years of age, acute anterior uveitis, ankylosing spondylitis, } \\
\text { inflammatory bowel disease with sacroiliitis, Reiter's syndrome or acute anterior uveitis in a } \\
\text { first-degree relative }\end{array}$ \\
\hline Undifferentiated arthritis & $\begin{array}{l}\text { Arthritis does not fulfill criteria for one of the above categories or } \\
\text { Arthritis fitting more than one of the above categories }\end{array}$ \\
\hline
\end{tabular}


Table 2. Pediatric core set criteria for improvement in juvenile idiopathic arthritis ${ }^{[16]}$

\begin{tabular}{|c|c|}
\hline Criteria & $\begin{array}{l}\text { 1. Number of active joints } \\
\text { 2. Number of joints with limited range of motion } \\
\text { 3. Physician's global assessment } \\
\text { 4. Parent's global assessment } \\
\text { 5. Functional ability (Childhood health assessment questionnaire) } \\
\text { 6. Erythrocyte sedimentation rate }\end{array}$ \\
\hline $\begin{array}{l}\text { American College of } \\
\text { Rheumatology Pediatric } 30 \\
\text { response (ACR Pedi 30) }\end{array}$ & $\begin{array}{l}\text { A minimum of } 30 \% \text { improvement in at least three out of six components, and a worsening of no } \\
\text { more than } 30 \% \text { in one component }\end{array}$ \\
\hline ACR Pedi 50 & $\begin{array}{l}\text { A minimum of } 50 \% \text { improvement in at least three out of six components, and a worsening of no } \\
\text { more than } 30 \% \text { in one component }\end{array}$ \\
\hline ACR Pedi 70 & $\begin{array}{l}\text { A minimum of } 70 \% \text { improvement in at least three out of six components, and a worsening of no } \\
\text { more than } 30 \% \text { in one component }\end{array}$ \\
\hline
\end{tabular}

such as the presence of uveitis, may influence treatment decisions. The present article will provide a brief update of clinical trial results and focus on recent evidence on the safety and efficacy of biologicals in the treatment of JIA.

Prior to the development of the pediatric core set and the American College of Rheumatology Pediatric 30 response criteria (ACR Pedi 30) in 1997, there had been no single, uniform definition of improvement for use in clinical trials of JIA(Table 2). ${ }^{[16]}$ The ACR Pedi 30 is used as the primary outcome measure for trials of biologic agents and second line therapies. Though not formally prospectively evaluated, the ACR Pedi 20, 50, 70, and 90 measures are also used as outcome measures in pediatric trials. The primary goal in the management of JIA is the achievement and maintenance of remission. Clinical criteria defining the disease state as inactive disease (ID) or clinical remission (CR) was developed in 2004 (Table 3). ${ }^{[17]}$
This definition includes six parameters, all of which have to be satisfied for a patient to be considered to have ID. However, they were modified recently and three changes were made to the provisional criteria (Table 3). ${ }^{[18]}$

Biologic agents have been designed to target key cytokines implicated in JIA including tumor necrosis factor- $\alpha$ (TNF- $\alpha$ ), Interleukin-1 (IL-1), and IL- 6 as well as signaling molecules involved in the regulation of T-cell and B-cell lymphocyte responses. ${ }^{[7]}$ In general TNF- $\alpha$ inhibitors are more beneficial for children with polyarticular disease than in those with SOJIA. ${ }^{[19]}$ This difference may be due to different cytokines underlying the inflammatory response for each subtype of disease. ${ }^{[20]}$ Interleukin-1 and IL-6 rather than TNF- $\alpha$ may be the predominant proinflammatory cytokines in SOJIA. ${ }^{[21-23]}$ Thus, biological agents that target IL-1 and IL-6 activity appear to be more successful in treating patients with SOJIA.

Table 3. Internationally accepted definitions for inactive disease and clinical remission in children with juvenile idiopathic arthritis ${ }^{[17]}$

\begin{tabular}{|c|c|}
\hline Criteria* $^{*}$ & $\begin{array}{l}\text { No joints with active arthritis } \\
\text { No fever, rash, serositis, splenomegaly or generalized lymphadenopathy } \\
\text { No active uveitis } \\
\text { Normal ESR or CRP (if both are tested, both must be normal) } \\
\text { Physician's global assessment of disease activity indicates no disease activity }\end{array}$ \\
\hline Inactive disease $\mathrm{e}^{\star *}$ & If the patient simultaneously meet all of the above criteria \\
\hline Clinical remission on medication & $\begin{array}{l}\text { If the patient demonstrate inactive disease consistently for at least six months while on } \\
\text { medication for treatment of JIA }\end{array}$ \\
\hline Clinical remission off medication & $\begin{array}{l}\text { If the patient demonstrate inactive disease consistently for at least six months while off } \\
\text { medication for treatment of JIA }\end{array}$ \\
\hline
\end{tabular}




\begin{tabular}{|c|c|}
\hline Injection site & $\begin{array}{l}\text { Local erythema and swelling which usually subsides within } 24 \text { hours. For adalimumab } \\
\text { there is greater immediate pain at the site of injection when compared to etanercept }\end{array}$ \\
\hline Infusion reactions & $\begin{array}{l}\text { During infusion or within one hour following completion of an infusion of infliximab, } \\
\text { fever, chills, nausea, sensation of thoracic constriction, dyspnea, flushing, urticaria, } \\
\text { anaphylactic reaction }\end{array}$ \\
\hline $\begin{array}{l}\text { Developments of antibodies } \\
\text { that neutralise the drug }\end{array}$ & $\begin{array}{l}\text { More common with infliximab, which is a chimeric } \mathrm{mAb} \text { and the most immunogenic of } \\
\text { the anti-TNF- } \alpha \text { biologicals }\end{array}$ \\
\hline $\begin{array}{l}\text { Development of newly induced } \\
\text { ANA and anti-dsDNA }\end{array}$ & More common with infliximab treatment \\
\hline Increased risk of severe infections & E.g. sepsis, pneumonia, herpes simplex and zoster infection, pyelonephritis \\
\hline $\begin{array}{l}\text { Increased risk of opportunistic } \\
\text { infections }\end{array}$ & E.g. histoplasmosis or coccidioidomycosis \\
\hline Reactivation of silent tuberculosis & - \\
\hline $\begin{array}{l}\text { New onset or exacerbation of } \\
\text { CNS demyelinating disorders }\end{array}$ & $\begin{array}{l}\text { Depression, headache, vertigo, fatigue, hyperactivity, nervousness, anxiety, pain } \\
\text { amplification, panic attacks, anorexia nervosa, optic neuropathy, hypoglossal paralysis } \\
\text { that have been reported, especially in patients using etanercept }\end{array}$ \\
\hline $\begin{array}{l}\text { New onset of inflammatory } \\
\text { bowel diseases }\end{array}$ & - \\
\hline $\begin{array}{l}\text { Possible reactivation of chronic } \\
\text { iridocyclitis }\end{array}$ & - \\
\hline $\begin{array}{l}\text { Increased risk of malignancy } \\
\text { especially lymphoma }\end{array}$ & It is unclear whether these agents are associated with an increased risk of malignancy or not \\
\hline Soft tissue infections & - \\
\hline
\end{tabular}

\section{TNF- $\alpha$ INHIBITORS IN JUVENILE IDIOPATHIC ARTHRITIS}

Tumor necrosis factor- $\alpha$ is a proinflammatory cytokine. Elevated TNF- $\alpha$ levels have been identified in plasma and synovial fluid in patients with JIA ${ }^{[24]}$ justifying that it is a major contributor to the inflammatory synovitis and joint damage in JIA. Tumor necrosis factor- $\alpha$ inhibitors are biological agents that block the immunological effects of this inflammatory mediator. Inhibitors of TNF- $a$ were evaluated for efficacy in controlling JIA and have been shown to be highly effective in the treatment of JIA patients whose disease has been unresponsive to traditional therapies. ${ }^{[25,26]}$ It has become common practice to move directly to anti-TNF therapy for the treatment of arthritis in children who have failed to respond adequately to MTX or who have been unable to tolerate MTX due to adverse effects. ${ }^{[27,28]}$ There are three TNF- $\alpha$ inhibitors available for clinical use in the treatment of JIA: Etanercept (Enbrel), infliximab (Remicade) and adalimumab (Humira).

\section{Etanercept}

Etanercept (Enbrel) is a soluble p75 TNF receptor fusion protein coupled to the Fc (fragment crystallizable region) fragment of immunoglobulin G1 (IgG1) that acts competitively to inhibit the binding of both TNF- $\alpha$ and TNF- $\beta$ to their cell surface receptors. Etanercept binds its target cytokine only when it is in serum and lowers the quantity of free TNF- $\alpha$ available for the maintenance of the inflammatory synovitis of JIA. Etanercept is administered as a subcutaneous injection 1-2 times per week. The TNF inhibitor etanercept is the first biological approved by the U.S. Food and Drug Administration (FDA) for treatment of moderate to severe polyarticular JIA in children aged two years and older. It can be used alone or as an adjunct to MTX.

Tumor necrosis factor- $\alpha$ inhibitors, including etanercept, appear to have a more rapid onset of clinical effect than conventional DMARDs. In general, clinical improvement should be seen within 4-12 weeks. ${ }^{[27,29]}$ However, these biologicals have not been shown to induce long-term clinical remission while patients were off medication. In a multicenter, randomized controlled trial (RCT), Lovell et al. ${ }^{[30]}$ enrolled 69 children aged 4 to 17 years with DMARDrefractory polyarticular JIA. In a three-month open label phase, all patients received etanercept at a dose of $0.4 \mathrm{mg} / \mathrm{kg}$ twice a week and nearly $75 \%$ of patients 
achieved an ACR Pedi 30. Dramatic improvements were achieved within weeks after commencement of therapy. Those patients who met the predefined definition of response at three months were randomized to continue etanercept or be switched to a placebo for four months. In the double-blind part of the study, $81 \%$ of the patients who were randomized to a placebo demonstrated disease flare compared with $28 \%$ of those who continued on etanercept. Thus, in most children, etanercept's effects cease within a few weeks of its discontinuation. This study also showed that etanercept produced significant improvement in disease activity when used in the absence of DMARDs and appeared to be less effective in patients with SOJIA. Etanercept has demonstrated sustained improvement in the signs and symptoms of polyarticular-course JIA with an acceptable safety profile in an open-label extension (OLE) of a RCT at four and eight years. ${ }^{[31,32]}$ At an eight-year follow-up, an ACR Pedi 70 was achieved by $61 \%$ of patients.

A 2008 systematic review of synthetic and biologic DMARD therapy for RA in adult patients concluded that anti-TNF monotherapy was similar in efficacy to treatment with MTX alone. The combination of an anti-TNF agent with MTX reduced disease activity more than did anti-TNF monotherapy or MTX alone. ${ }^{[33]}$ In children, nonrandomized open-label studies of the TNF inhibitors etanercept and infliximab have shown that these biologicals safely control active disease when used in combination with traditional therapies. ${ }^{[34,35]}$ In 2008, a German registry also provided information on 431 children treated either with etanercept alone or with the combination of etanercept and MTX. At 12 months of follow up, the number of patients with JIA reaching a ACR Pedi 70 response was significantly higher in the etanercept and MTX group than in the etanercept monotherapy group. ${ }^{[36]}$

Etanercept can induce disease remission and prevent both clinical and radiological disease progression with significant improvements in symptoms, function and quality of life. ${ }^{[37,38]}$ In another small study, bone mineral status improved in patients who had responded to and continued etanercept treatment for more than one year. ${ }^{[39]}$

Currently, little is known about when or how to stop etanercept in patients with JIA when a good clinical response is reached. Prince et al. ${ }^{[40]}$ suggest that patients with JIA should meet the criteria of clinical remission of medication for at least 1.5 years before considering discontinuation of etanercept and then taper off it carefully. In addition, issues such as whether etanercept should be used before MTX (faster onset of action, possibly more effective and less toxic) remain to be resolved. As more biologic agents become available over the next decade, there may be dramatic changes in our approach to the treatment of JIA.

\section{Infliximab}

Infliximab (Remicade) is a chimeric mouse-human monoclonal antibody $(\mathrm{mAb})$ that binds specifically to human TNF- $a$ with high affinity (mAbs have a higher affinity for a given cytokine than do soluble receptors like etanercept) and neutralises the biological activity of TNF- $\alpha$ by inhibiting its binding to its receptor. ${ }^{[27]}$ In JIA, MTX must be added to infliximab to prevent the development of neutralising antibodies to infliximab that could reduce its therapeutic efficacy. Monoclonal antibodies (infliximab and adalimumab) bind their target not only when it is free in the serum (like etanercept does), but also when it is bound to the cell surface. They do not bind TNF- $\beta$. They have a higher affinity for a given cytokine than do soluble receptors. Like etanercept, they lower the quantity of TNF- $\alpha$ available to maintain an inflammatory response. İnfliximab is given as an intravenous infusion on a monthly to eight-weekly timetable. Infliximab has FDA approval for use in adult RA, psoriasis and adult and pediatric Crohn's disease, but not in JIA.

In a multicenter RCT, Ruperto et al. ${ }^{[4]}$ enrolled 122 children aged 4 to 17 years with polyarticular JIA refractory to MTX and randomized patients to receive infliximab ( $3 \mathrm{mg} / \mathrm{kg} / \mathrm{dose})$ or a placebo for 14 weeks. After 14 weeks, all children received infliximab through week 44. Patients received MTX plus infliximab $3 \mathrm{mg} / \mathrm{kg}$ through week 44, or MTX plus placebo for 14 weeks followed by MTX plus infliximab $6 \mathrm{mg} / \mathrm{kg}$ through week 44 . At 14 weeks, a higher proportion of patients randomized to infliximab $3 \mathrm{mg} / \mathrm{kg}$ had an ACR Pedi 30 response when compared with patients in the placebo group, but this difference was not statistically significant. By week 52, clinical responses meeting the ACR Pedi 50 and ACR Pedi 70 criteria were reached by $70 \%$ and $52 \%$ of the patients respectively. There were no statistically significant differences between the infliximab dose groups. Ruperto et al. ${ }^{[42]}$ also assessed the long-term safety and efficacy of MTX plus two infliximab dosages $(3 \mathrm{mg} / \mathrm{kg}$ or $6 \mathrm{mg} / \mathrm{kg})$ in a threeyear OLE. At week 204, the proportions of patients achieving ACR-Pedi 30/50/70/90 response criteria and inactive disease status were $44 \%, 40 \%, 33 \%, 24 \%$, and $13 \%$ respectively, and they concluded that in the limited population of JIA patients remaining in the 
study through four years, infliximab was safe and effective even though it was associated with a high patient discontinuation rate.

One small observational study compared the administration of infliximab to etanercept in children with polyarticular JIA who had not responded to conventional DMARDs and showed similar results (ACR Pedi 50 improvement of 80 to 90 percent) in the two groups after 12 months of treatment. ${ }^{[34]}$

One of the unique and distressing complications of JIA is a chronic, non-granulamatous uveitis. Tynjälä et al. ${ }^{[43]}$ enrolled 45 patients to compare the efficacy of infliximab with that of etanercept in the treatment of chronic uveitis; 24 patients were receiving etanercept and 21 were receiving infliximab. Patients who were taking infliximab were more likely to improve than those taking etanercept. ${ }^{[43]}$ Richards et al. ${ }^{[44]}$ and Rajaraman et al. ${ }^{[45]}$ each reported six cases of JIAassociated uveitis which were poorly responsive to other therapies. These patients were then treated with infliximab and had significant improvement under this therapy. Recently, the results of a multinational survey were reported. In this study etanercept was used in 34 patients and infliximab in 25 patients. The response to etanercept was favourable in about $50 \%$ of the cases, moderate in about $15 \%$, and poor in about $35 \%$, and for infliximab the response was favourable in about $69 \%$ of the cases, moderate in about $31 \%$, and poor in $0 \%{ }^{[46]}$ These studies demonstrate that infliximab is more effective than etanercept in the treatment of refractory uveitis.

\section{Adalimumab}

Adalimumab (Humira) is a recombinant fully human $\mathrm{mAb}$ which is administered either weekly or, more commonly, every other week as a single subcutaneous injection rather than by intravenous infusion. Adalimumab is associated with a lower risk of antibody formation compared with infliximab because of its fully humanised structure. In 2008, adalimumab was approved by the FDA as the second TNF- $\alpha$ inhibitor for the treatment of moderate to severe JIA in patients aged four years and older.

In a multicenter, randomized, medicationwithdrawal study, Lovell et al. ${ }^{[47]}$ enrolled 171 children aged 4 to 17 years with active polyarticular JIA. Children were stratified according to MTX use and received adalimumab subcutaneously every other week for 16 weeks. In a manner similar to the etanercept trial, after an open-label lead-in phase of 16 weeks, patients with ACR Pedi 30 response were randomly selected in a double blind manner to receive adalimumab or a placebo for an additional 32 weeks. In the second phase of the study, patients receiving adalimumab had significantly fewer flare-ups than patients in the placebo group regardless of whether they received MTX or not. Adalimumab demonstrated sustained improvement during two years of treatment. After 104 weeks of OLE treatment, the proportions of patients achieving ACR-Pedi 50/70/100 response criteria were $86 \%, 77 \%$, and $40 \%$, respectively.

Eighteen patients with uveitis were treated with adalimumab. The patients had all failed to respond to systemic steroids, cyclosporin, MTX, leflunomide, etanercept or infliximab. Sixteen out of 18 patients had good responses to adalimumab. ${ }^{[48]}$ In another retrospective observational study by Tynjälä et al., ${ }^{[49]}$ of 20 patients with chronic uveitis treated with adalimumab, 19 of them had been previously treated with infliximab or etanercept. Of the 20 patients, seven showed improved activity, one showed worsening activity, and twelve showed no change in the activity of uveitis. The mean number of flares/year decreased from 1.9 to 1.4 during adalimumab treatment, but this change was not significant. These studies suggest that adalimumab is a potential treatment option in JIAassociated uveitis, even in patients not responsive to other previous anti-TNF therapies.

There is no clear evidence to support the superiority of one TNF- $\alpha$ inhibitor over another and failure to respond to one agent does not preclude response to another. ${ }^{[50,51]}$ In one small study, it was shown that using a third anti-TNF agent, adalimumab, can be efficacious in patients with JIA refractory to etanercept and/or infliximab.

\section{Adverse effects of anti TNF- $\alpha$ biological agents}

In order to use TNF- $\alpha$ inhibitors appropriately, it is important to be aware of potential treatment-related adverse effects (AEs) of these biologicals and the differences between them (Table 4). As well as with other DMARDs, SOJIA is at a greater risk for AEs than non-systemic JIA categories.

The most common AEs of TNF- $\alpha$ inhibitors are injection site reactions to subcutaneously administered drugs (etanercept and adalimumab) or infusion reactions (IRs) with infliximab. The cutaneous injection site reaction consists of local erythema and swelling which usually subsides within 24 hours. Transient injection site reactions are described in about 
$39 \%$ of patients with JIA on etanercept. ${ }^{[30]}$ In addition to the adverse effects reported above, there is greater immediate pain at the site of adalimumab injections when compared to etanercept, but this is generally an inconvenience that children find bearable. ${ }^{[47]}$ Infusionrelated reactions were defined as any adverse event that occurred during or within one hour following completion of an infusion. Infusion reactions are the most common AEs in patients treated with infliximab $(26-38 \%)^{[41,52]}$ and the reason for withdrawal among those receiving infliximab. These reactions are possibly due to immune responses against the mostly humanized mouse monoclonal antibody. In the international trial, IRs occurred in approximately $26 \%$ and $32 \%$ of patients from weeks 0-52 and 52-204 (OLE) respectively, with a higher incidence in patients positive for antibodies to infliximab, and were more frequent in patients treated with the lower $3 \mathrm{mg} / \mathrm{kg}$ dosage than the $6 \mathrm{mg} / \mathrm{kg}$ dose. ${ }^{[41,42]}$ Serious IRs occurred in eight patients wherein five patients had a possible anaphylactic reaction. Gerloni et al. ${ }^{[52]}$ enrolled 163 children (68 infliximab, 95 etanercept). In their trial, the greater number of patients who presented AEs with infliximab (62.9\%) versus those with etanercept $(54.3 \%)$ was due to IRs (sensation of thoracic constriction, dyspnea, flushing, urticaria). Infusion reactions were the most common AEs (38.3\%), and $20.1 \%$ of patients suspended treatment because of severe IR relapse. In this study, 12 patients receiving etanercept manifested a diffuse cutaneous reaction that led to withdrawal in only two patients. Most centers report a similarly increased incidence of side effects in children treated with mAbs, especially infliximab relative to etanercept. Since adalimumab is also administered subcutaneously, but only every other week, this $\mathrm{mAb}$ is at least administered as easily as etanercept.

One of the major concerns with infliximab is the development of human anti-chimeric antibodies (HACA) that neutralise the drug, thereby limiting its long-term efficacy or causing IRs. In an international trial, $25 \%$ of all patients had antibodies to infliximab with a higher incidence in the infliximab $3 \mathrm{mg} / \mathrm{kg}$ group (38\%) compared with the infliximab $6 \mathrm{mg} / \mathrm{kg}$ group (12\%). ${ }^{[41]}$ Infliximab seems to be more frequently responsible for newly induced anti-nuclear antibody (ANA) and anti-double stranded DNA (anti-dsDNA) antibody. During the OLE, newly positive ANA and anti-dsDNA occurred in $26 \%$ and $7 \%$ of patients from weeks 52-204. ${ }^{[42]}$ However, only rare cases of druginduced systemic lupus erythematosus (SLE), discoid lupus erythematosus (LE) and cutaneous vasculitis are described. In another international trial, Lovell et al. ${ }^{[4]}$ reported that approximately $16 \%$ of the patients had anti-adalimumab antibodies. This percentage is greater than the $5 \%$ observed during clinical trials of adult patients with RA. ${ }^{[53]}$ Positive anti-adalimumab antibody tests were less frequent among those receiving concomitant MTX than among those receiving adalimumab monotherapy.

Serious adverse events (SAEs) are defined as events that are fatal or life-threatening, require hospitalization or prolong an existing hospitalization. SAEs cause a persistent or significant disability or incapacity, a congenital anomaly, or birth defect. Etanercept offers an acceptable safety profile in long-term treatments. ${ }^{[31]}$ The long-term safety profile of etanercept was maintained for up to eight years of continuous drug use. ${ }^{[32]}$ Exposure-adjusted rates of SAEs did not increase over time, and the most common new SAEs reported beyond four years of drug exposure were flare or worsening of disease. Between the fourth and eighth year of follow-up, a single case of pyelonephritis was the only additional infection reported. It is thought that the three TNF- $\alpha$ inhibitors will share a similar long-term side effect.

The most important adverse effect of anti-TNF- $\alpha$ therapy is the increased risk of severe infections (e.g. sepsis, pneumonia, herpes simplex and zoster infection, pyelonephritis). After four years of an international trial of etanercept, the overall rate of SAEs was 0.13 and of serious infections was 0.04 per patient-year. ${ }^{[31]}$ The overall rate of SAEs (0.12 per patient-year) did not increase with long-term exposure to etanercept. Similarly, SAEs occured only in 14/171 patients, seven of whom had serious infections in the adalimumab trial. ${ }^{[47]}$ In the infliximab trial, however, the overall rate of SAEs (24/117) was higher, six of whom had serious infections. ${ }^{[41]}$ In addition, there may be an increased risk of opportunistic infections, particularly fungal (e.g. histoplasmosis or coccidioidomycosis) with the use of these agents. In patients who develop serious infections, the TNF- $\alpha$ blocker should be ceased, at least until the complete resolution of the infection. ${ }^{[27]}$ The reactivation of silent tuberculosis (TB), definitely related to TNF- $\alpha$ inhibition, has completely disappeared as TB screening and prophylaxis are now the rule before antiTNF- $\alpha$ therapy. ${ }^{[52]}$ Infliximab is associated with the greater risk. ${ }^{[54]}$

Over an 11-year period (1998-2009), 48 cases of malignancies in children with a TNF inhibitor have been reported to the FDA Adverse Event Reporting 
System. Half of them were lymphomas, including Hodgkin's and non-Hodgkin's lymphoma; the rest included leukemia, melanoma, and solid organ cancers. Therefore, the FDA concluded that there is an increased risk of malignancy with TNF blockers. However, due to the relatively rare occurrence of these cancers, the limited number of pediatric patients treated with TNF blockers, and the possible role of other immunosuppressive therapies used concomitantly with TNF blockers, the FDA is unable at this time to fully characterize the strength of the association between using TNF blockers and developing a malignancy. New-onset or relapsing central nervous system (CNS) demyelinating disorders and neuropsychiatric AEs (depression, headache, vertigo, fatigue, hyperactivity, nervousness, anxiety, pain amplification, panic attacks, anorexia nervosa, optic neuropathy, hypoglossal paralysis) have been reported, especially in patients using etanercept. ${ }^{[52]}$ New-onset inflammatory bowel diseases (IBD) have also been detected in patients treated with etanercept. ${ }^{[52]}$ Another concern with TNF- $\alpha$ blockers, especially with etanercept, is the possible reactivation of chronic iridocyclitis (CIC). ${ }^{[52]}$ TNF- $\alpha$ inhibitors are effective in treating JIA and have acceptable safety profiles, but because of all these possible AEs, it is suggested that these biologic agents be used in patients with severe disease that is refractory to conventional therapy.

\section{Interleukin-1 inhibitors}

Interleukin-1 is a proinflammatory cytokine that triggers the production of proinflammatory prostoglandins as well as such other proinflammatory cytokines as IL- 6 and TNF- $\alpha$. Pascual et al., ${ }^{[23]}$ reported that IL-1 is a major mediator of the inflammatory cascade that underlies SOJIA. This study demonstrated that sera from patients with SOJIA could provoke IL-1 synthesis in tissue cultures of mononuclear cells from healthy controls, and this cytokine represents a target for therapy in this disease. Anakinra is currently in use in children with JIA while several other IL-1 inhibitors (rilonacept and canakinumab) are under investigation.

\section{Anakinra}

Anakinra (Kineret) is a recombinant IL-1 receptor antagonist (IL-1 Ra) that is approved for use in RA. Because of its short half-life, it is administered daily by subcutaneous injection (1-2 mg/kg/day). The Anakinra in Systemic-Onset Juvenile Idiopathic Arthritis trial (ANAJIS trial) was the the only double-blind RCT which tested anakinra efficacy in 24 patients with refractory SOJIA. Preliminary results reported in abstract form demonstrated that at one month, there was a significant difference in the response rate between patients treated with anakinra (8/12) and a placebo (1/12). Ten patients from the placebo group switched to anakinra at month one and nine were responders at month two. Gene expression profile analyses showed a set of gene pathways dysregulated in SOJIA whose expression dramatically changed upon anakinra treatment. ${ }^{[55]}$

The first report on the effectiveness of IL-1Ra in SOJIA was presented in 2002. In an open-label study by Reiff, ${ }^{[56]} 80$ patients with various forms of JIA were treated with anakinra; patients with SOJIA had a better response to anakinra than did those with other types of JIA (11/15 responded to anakinra). A similar recent $\mathrm{RCT}$ of anakinra $(1 \mathrm{mg} / \mathrm{kg} /$ day; maximum 100 $\mathrm{mg}$ /day) versus placebo in 50 patients with JIA by Ilowite et al. ${ }^{[57]}$ was unable to demonstrate significant efficacy of the drug. Subgroup analysis, however, showed that response rates may be higher among patients with SOJIA. Recent case reports demonstrated that treatment with IL-1 Ra (anakinra) led to rapid and sustained remission within a few days following the initiation of anakinra injections in patients with SOJIA who had been resistant to conventional DMARDs including TNF-blockade. ${ }^{[21,58-60]}$ An initial case series reported by Pascual et al. ${ }^{[23]}$ reported a dramatic response to IL-1 blockade among SOJIA patients with six out of nine patients treated with anakinra achieving complete remission and two having improvement in symptoms. The results obtained in this case series support the use of anakinra as second-line therapy in children with SOJIA who have failed to respond to standard therapy.

Lequerré et al. ${ }^{[6]]}$ recently described 20 SOJIA patients treated with anakinra and found marked and sustained improvement in less than half of the cases. Similarly, Gattorno et al. ${ }^{[62]}$ described a variable response of patient's arthritis to anakinra in their series of 22 cases. In addition, Zeft et al. ${ }^{[63]}$ reported that arthritis was less improved compared with the general systemic symptoms of the disease. These observations indicate that although anakinra is considered to be effective in SOJIA, there is a group of patients who are anakinraresistant. The blockade of IL-1 signalling has a dramatic and sustained effect in some patients with the cessation of symptoms and a significant decrease of acute phase markers. The large group of partial responders and non-responders are suggestive of pathological processes that are independent of the IL-1 pathway. ${ }^{[64,65]}$ 
Injection site reactions (itch and/or erythema) and injection pain with daily subcutaneous medication are frequent local effects of anakinra ${ }^{[60,61,63]}$ which may be so severe as to require the stoppage of medication. In the study by Zeft et al., ${ }^{[63]}$ over half of the patients reported localized pain or swelling at their injection sites. Similar to TNF- $\alpha$ inhibitors, IL-1 blockade increases the risk of infections. Anakinra is not recommended in a combined regimen with a TNF inhibitor because of an increased frequency of serious adverse events, including serious infections. ${ }^{[6]]}$ In the ANAJIS trial, eight patients discontinued anakinra before month 12 . Two patients (both on placebos) had painful injections during the double-blind phase, one had ileocolic symptoms leading to the diagnosis of Crohn's disease, and one had a case of transient hepatic cytolysis. There was also a lack of efficacy or a disease flare in four cases. ${ }^{[55]}$ Varicella, localized herpes, leishmaniasis and EBV infections have been described in children with SOJIA receiving anakinra. ${ }^{[61,63]}$ Three cases of macrophage activation syndrome (MAS) have also been described. ${ }^{[62,63]}$ Anakinra has also been used to sufficiently treat MAS in SOJIA patients. ${ }^{[67,68]}$ Without well-designed trials, the attributability of these findings remains unclear, and the ultimate long-term safety profile of anakinra needs to be determined.

\section{Rilonacept}

Rilonacept (IL-1 Trap/Arcalyst) is a long-acting IL-1 blocker currently undergoing trials in children with SOJIA. Rilonacept is a recombinant fusion protein that combines IL-1 receptor protein components with the Fc portion of the human immunoglobulin molecule. Unlike anakinra, which requires daily dosing, rilonacept is administered once a week. ${ }^{[7]}$ Preliminary results of a double-blind, placebo-controlled study of rilonacept (2.2 to $4.4 \mathrm{mg} / \mathrm{kg} /$ week) in SOJIA were reported by Lovell et al. ${ }^{[69]}$ in abstract form. Of the 21 patients enrolled in the trial, 12 remain in the openlabel study and have had good responses to rilonacept with 10 patients achieving an ACR Pedi 70 response at 42 weeks. Six out of seven patients who had failed to respond to anakinra were found to improve on rilonacept. Adverse events were mild or moderate in severity included generalized rash and mood alteration. SAEs included exacerbation of pancy topenia and MAS. The OLE study on rilonacept in SOJIA was presented at the ACR 2009 meeting. In this long-term OLE study, sustained responses were observed in clinical and laboratory assessments in over $50 \%$ of patients with SOJIA at two years. There was a significant reduction in daily prednisone dosage. No deaths, malignancies, or serious infections occurred. The authors suggested that chronic IL-1 blockade with rilonacept was generally safe and well-tolerated. ${ }^{[70]}$

\section{Canakinumab}

Canakinumab (ACZ885) is a fully humanized $\mathrm{mAb}$ which binds specifically to the $\beta$ isoform of IL-1 (IL-1 $\beta$ ) and neutralizes the bioactivity of human IL-1 $\beta$. It is administered as either a subcutaneous injection or an intravenous infusion. Canakinumab shows encouraging efficacy and is well tolerated in children with SOJIA according to a new phase II study presented at PReS 2009, a joint congress with the 2009 Congress of the European League Against Rheumatism (EULAR) in Copenhagen, Denmark. This open-label staggered dose-escalation study assessed 23 children with active disease receiving a single subcutaneous injection of canakinumab in the dose range $0.5-9 \mathrm{mg} / \mathrm{kg}$. Of those patients who responded to treatment (59\% of initial enrollers), 100\% achieved the ACR Pedi 50 score within only 15 days of receiving canakinumab. Adverse events were predominantly mild to moderate in severity and included infections and gastrointestinal disorders. SAEs including worsening nausea in a patient with a medical history of gastritis and EBV infection in another patient relating to canakinumab resolved during treatment. Early clinical trials have established the administration of canakinumab every two weeks to be safe and effective offering a considerable advantage over existing treatment with anakinra which must be injected daily and which is often poorly tolerated by patients..$^{[71]}$

\section{IL-6 INHIBITOR: TOCILIZUMAB}

Tocilizumab (Roactemra/Actemra/MRA) is a recombinant humanized monoclonal antibody that acts as an IL-6 receptor antagonist that has not yet been approved by the FDA for the treatment of RA or JIA. Interleukin- 6 has both proinflammatory and anti-inflammatory effects. Plasma levels of IL-6 have been demonstrated to correlate with disease activity in JIA patients, and particularly elevated IL-6 levels have been noted in patients with SOJIA. ${ }^{[2]}$ In general, patients with SOJIA have a higher rate of treatment failure with TNF- $\alpha$ inhibitors than those with other chronic arthritis subtypes indicating that TNF- $\alpha$ is not the only cytokine implicated in the pathogenesis of the disease. ${ }^{[72]}$ Although it is likely that the blockade of IL-1 has a dramatic and sustained effect in some patients with SOJIA, the large group of partial responders and non-responders 
suggests pathological processes independent of the IL-1 pathway. ${ }^{[64]}$ Therapy with an anti-IL-6-receptor antibody (tocilizumab) revealed much better response rates in two phase II studies in SOJIA ${ }^{[73,74]}$ and, more recently, in poly- and oligoarticular onset disease. ${ }^{[75]}$ A randomized clinical trial is needed to define efficacy and to identify the proper target population. This response rate is likely to be due to the fact that IL- 6 can be stimulated by IL- 1 and TNF; therefore, a blockade of IL- 6 will take care of processes that come mainly from the IL-1 or TNF pathways as well other sources of stimulation of IL-6 in this disease. ${ }^{[64]}$

In a phase III trial by Yokota et al., ${ }^{[76]} 56$ children (aged 2-29 years) with SOJIA refractory to conventional treatment were given three doses of tocilizumab $8 \mathrm{mg} / \mathrm{kg}$ every two weeks as intravenous infusions during a six week open-label lead-in phase. The trial design was similar to the etanercept trial. Patients who achieved ACR Pedi 30 response and C-reactive protein concentration (CRP) of less than $5 \mathrm{mg} / \mathrm{L}$ were randomly assigned to receive a placebo or continue tocilizumab treatment for 12 weeks. Patients responding to tocilizumab and needing further treatment were enrolled in an OLE phase for at least 48 weeks. After the end of the openlabel phase, ACR Pedi 30, 50, and 70 responses were achieved by 51 (91\%), $48(86 \%)$ and $38(68 \%)$ of patients respectively. Forty-three patients continued to the double-blind phase. Four (17\%) of the 23 patients in the placebo group compared to $16(80 \%)$ of the 20 patients in the tocilizumab group maintained an ACR Pedi 30 response and a CRP concentration of less than $15 \mathrm{mg} / \mathrm{L}$. ACR Pedi 30, 50, 70 responses were achieved by 47 (98\%), 45 (94\%) and 43 (90\%) of 48 patients, respectively. SAEs occured in 13 of 50 patients during the OLE phase. These included anaphylactoid reactions, gastrointestinal hemorrhages and bronchitis.

Interleukin-6 may also play a role in complications of SOJIA such as growth impairment, systemic osteoporosis and amyloidosis. ${ }^{[77]}$ In this respect, in a small group of SOJIA patients, cartilage oligomeric matrix protein (COMP) levels were found to be lower than controls and they markedly increased under tocilizumab therapy. These findings suggested that in SOJIA patients, the growth cartilage turnover was suppressed during the active disease phase, but it improved in the remission phase after tocilizumab treatment. ${ }^{[78]}$

\section{T-CELL COSTIMULATION MODULATOR;} ABATACEPT

Abatacept (Orencia/CTLA4-Ig) is a fully human, soluble fusion protein with a unique mechanism of action. Abatacept consists of the extracellular domain of the cytotoxic T-lymphocyte-associated antigen 4 (CTLA-4) and the Fc portion of the immunoglobulin G1 (IgG1). CTLA4-Ig binds with either CD80 (B7-1) or CD86 (B7-2) on antigen-presenting cells, thereby acting as a competitive inhibitor of the CD28-B7 costimulatory interaction and preventing the second activation signal received by $\mathrm{T}$ cells via CD28. Abatacept thus downregulates T-cell stimulation and potentially affects many downstream cytokines and cell types that have been implicated in the pathogenesis of JIA.

In 2008, abatacept was approved by the FDA for treatment of patients aged six years or older with moderate to severe polyarticular JIA. The European Medicines Agency (EMEA) also recently (2010) approved abatacept in combination with MTX for the treatment of moderate to severe polyarticular JIA in pediatric patients six years of age and older as a second line biologic after TNF inhibitors. Abatacept has been studied in a double-blind, randomized controlled withdrawal trial including 190 children aged 6-17 years old with active polyarticular JIA refractory to at least one previous DMARD agent including anti-TNF agents. ${ }^{[7]}$ The design of this pivotal study was similar to trials of the anti-TNF agents (etanercept and adalimumab) and tocilizumab. All patients were given $10 \mathrm{mg} / \mathrm{kg}$ of abatacept intravenously in the open-label period of four months. At the end of the open-label treatment period, two-thirds of the 190 enrolled patients had improved by $30 \%$ or more according to ACR Pedi response criteria. Of the patients who did respond to abatacept, 60 were randomly assigned to receive $10 \mathrm{mg} / \mathrm{kg}$ abatacept at 28-day intervals for six months, and 62 were randomly assigned to receive a placebo. Flares of arthritis occured in 33 of $62(53 \%)$ patients receiving placebo and 12 of 60 (20\%) patients receiving abatacept $(\mathrm{p}=0.0003)$. During the double-blind period, there was no difference in the frequency of AEs between the two groups. Few SAEs were reported with no serious infections, opportunistic infections, or serious autoimmune disorders.

Abatacept was also used in a case of refractory JIA uveitis resistant to infliximab and rituximab, and the response was good. ${ }^{[80]}$ Abatacept may be a useful alternative for treating JIA children with associated uveitis and must, therefore, be considered as a viable treatment option. 


\section{OTHER AGENTS}

\section{Rituximab}

Rituximab (MabThera/Rituxan), a selective B-celldepleting agent, is a chimeric anti-CD20 mAb. B lymphocytes have been implicated in the pathogenesis of rheumatoid synovitis. The precise role of B cells has not been elucidated, but potential mechanisms include an antigen-presenting function, secretion of proinflammatory cytokines and costimulation of $\mathrm{T}$ cells. In this context, B cell depletion with rituximab has recently emerged as a potential treatment option for patients with RA. In randomized controlled studies, rituximab has been shown to be effective in patients with $\mathrm{RA}^{[81,82]}$ and approved by the FDA for treatment of adult patients with moderate to severe RA. There are few published case reports on the use of rituximab in children with refractory JIA. ${ }^{\left[{ }^{83-85]}\right.}$ On the other hand, in an oral presentation at the $3^{\text {rd }}$ Europaediatrics Congress 2008, Alexeyeva et al ${ }^{[86]}$ reported on 33 patients (16 boys and 17 girls) with severe systemic $(\mathrm{n}=24)$ or articular $(n=9)$ JIA refractory to immunosuppressive therapy including oral and parenteral glucocorticoids treated with rituximab. In this study, 24 patients refractory to TNF- $\alpha$ blockers and rituximab had been shown to produce a marked therapeutic effect including a decrease in clinical and laboratory disease activity parameters. They suggested that rituximab might be a promising therapeutic option in severe refractory JIA. Thus, further RCTs are needed to clarify the role of rituximab in children with severe refractory JIA.

\section{Thalidomide}

Thalidomide (thalomid) is a synthetic derivative of glutamic acid (alpha-phthalimido-glutarimide) with teratogenic, immunomodulatory, anti-inflammatory and anti-angiogenic properties. Thalidomide acts primarily by inhibiting both the production of TNF- $\alpha$ in stimulated peripheral monocytes and the activities of interleukins and interferons. This agent also inhibits polymorphonuclear chemotaxis and monocyte phagocytosis. Preliminary studies have demonstrated that thalidomide may be beneficial for children with severe SOJIA. ${ }^{[87,88]}$ Lehman et al. ${ }^{[87]}$ reported the use of thalidomide in the dose range 2 to $5 \mathrm{mg} / \mathrm{kg} / \mathrm{day}$ administered orally in 13 children with refractory SOJIA. Ten of the 13 children had improved by $50 \%$ or more according to ACR Pedi response criteria. In an another small study, García-Carrasco et al ${ }^{[88]}$ reported three cases of recalcitrant SOJIA that had improved dramatically after treatment with thalidomide. The most serious toxicity associated with thalidomide is its documented human teratogenicity. Based on present knowledge, thalidomide must not be used at any time during pregnancy. Somnolence, dizziness, and rash are the most commonly observed AEs associated with the use of thalidomide. Thalidomide is also associated with peripheral neuropathy and neutropenia.

\section{Leflunomide}

Leflunomide (Arava), an orally administered inhibitor of pyrimidine synthesis, has been shown to be a safe and effective long-term therapy for adults with RA. ${ }^{[89]}$ In a multinational RCT, Silverman et al. ${ }^{[90]}$ enrolled 94 children aged 3 to 17 years to compare the safety and efficacy of oral leflunomide with oral MTX in the treatment of polyarticular JIA. At week 16, the rates of ACR Pedi 50 responses were $60 \%$ in the leflunomide group and $77 \%$ in the MTX group ( $\mathrm{p}=0.10)$, and the rates of ACR Pedi 70 responses were $43 \%$ and $60 \%$ respectively $(\mathrm{p}=0.14)$. In both groups, the improvements achieved at week 16 were maintained at week 48 . After 48 weeks of treatment, MTX and leflunomide both resulted in high rates of clinical improvement, and the ACR pedi 30,50 , and 70 responses were similar between the two groups $(79 \%, 76 \%$, and $70 \%$ for leflunomide, and $91 \%, 86 \%$, and $83 \%$ for MTX). The incidence of treatment-related AEs was similar in the leflunomide group and the MTX group. The most commonly reported AEs were gastrointestinal symptoms including liver function test abnormalities, headache, nasopharyngeal symptoms, and reversible alopecia. Like thalidomide, leflunomide is also a known teratogen, so women of childbearing potential must not be started on leflunomide until pregnancy is excluded.

\section{AUTOLOGOUS STEM CELL TRANSPLANTATION (ASCT)}

Autologous stem cell transplantation has been used in patients with severe resistant JIA. For children with severe disease who fail to achieve disease control despite the use of multiple drugs including anti-TNF and antiIL- 6 receptor treatment, both allogenic and ASCT may offer an alternative option for disease remission. However, the procedure still carries a high mortality rate for an illness that does not typically have a fatal outcome. Results from 34 children with refractory SOJIA (29 children) and polyarticular disease who have undergone ASCT at multiple centers across Europe have been published. ${ }^{\left[{ }^{[1]}\right.}$ Data demonstrated 18/34 (53\%) patients had a complete response, six showed a partial response, and seven did not respond. The incidence of infectious complications was high and three children 
died. All deaths occured in patients with SOJIA due to MAS complicated by infection. Autologous stem cell transplantation protocols were subsequently modified in 1999 to decrease the depletion of T-cells. After these changes, there have been no ASCT-related deaths among 11 patients who have received the modified regimen. ${ }^{[92]}$ Although this procedure has helped a number of children whose disease was intractable, the authors point to the risk of high treatment-related morbidity and mortality. It is hoped that with the help of more effective anticytokine treatments such highrisk procedures will not be necessary in the future.

In conclusion, juvenile idiopathic arthritis is the most common rheumatic childhood disease that is associated with significant morbidity including functional disability and ocular damage. Prior to the era of biologicals, more than $25 \%$ of polyarticular and nearly $50 \%$ of systemic patients with JIA had functional limitations, and two-thirds had radiographically evident damage five years after onset. New and exciting alternative medications are emerging for children resistant to standard therapy. New data from large RCTs have showed the efficacy of TNF- $\alpha$ inhibitors, the T-cell costimulation modifier abatacept, and leflunomide for the treatment of polyarticular JIA. Anti-IL-1 and anti-IL-6 biologicals, particularly for SOJIA patients, look very promising as well. The $\mathrm{mAbs}$ to TNF- $\alpha$ appear to be more effective in treating chronic uveitis associated with JIA than etanercept; however, treatment still needs to be developed. The hope is that recent changes in treatment approaches will result in marked improvement in long-term functional outcomes of patients with JIA.

\section{Declaration of conflicting interests}

The authors declared no conflicts of interest with respect to the authorship and/or publication of this article.

\section{Funding}

The authors received no financial support for the research and/or authorship of this article.

\section{REFERENCES}

1. Ravelli A, Martini A. Juvenile idiopathic arthritis. Lancet 2007;369:767-78.

2. Brewer EJ Jr, Bass J, Baum J, Cassidy JT, Fink C, Jacobs J, et al. Current proposed revision of JRA Criteria. JRA Criteria Subcommittee of the Diagnostic and Therapeutic Criteria Committee of the American Rheumatism Section of The Arthritis Foundation. Arthritis Rheum 1977;20(2 Suppl):195-9.
3. Andersson Gäre B. Juvenile arthritis-who gets it, where and when? A review of current data on incidence and prevalence. Clin Exp Rheumatol 1999;17:367-74.

4. Foster HE, Marshall N, Myers A, Dunkley P, Griffiths ID. Outcome in adults with juvenile idiopathic arthritis: a quality of life study. Arthritis Rheum 2003;48:767-75.

5. Packham JC, Hall MA, Pimm TJ. Long-term follow-up of 246 adults with juvenile idiopathic arthritis: predictive factors for mood and pain. Rheumatology (Oxford) 2002;41:1444-9.

6. Haines KA. Juvenile idiopathic arthritis: therapies in the 21st century. Bull NYU Hosp Jt Dis 2007;65:205-11.

7. Hayward K, Wallace CA. Recent developments in antirheumatic drugs in pediatrics: treatment of juvenile idiopathic arthritis. Arthritis Res Ther 2009;11:216.

8. Petty RE, Southwood TR, Baum J, Bhettay E, Glass DN, Manners P, et al. Revision of the proposed classification criteria for juvenile idiopathic arthritis: Durban, 1997. J Rheumatol 1998;25:1991-4.

9. Petty RE, Southwood TR, Manners P, Baum J, Glass DN, Goldenberg J, et al. International League of Associations for Rheumatology classification of juvenile idiopathic arthritis: second revision, Edmonton, 2001. J Rheumatol 2004;31:390-2.

10. Lovell DJ. Update on treatment of arthritis in children: new treatments, new goals. Bull NYU Hosp Jt Dis 2006;64:72-6.

11. Levinson JE, Wallace CA. Dismantling the pyramid. J Rheumatol Suppl 1992;33:6-10.

12. Wallace CA, Huang B, Bandeira M, Ravelli A, Giannini EH. Patterns of clinical remission in select categories of juvenile idiopathic arthritis. Arthritis Rheum 2005;52:3554-62.

13. Giannini EH, Brewer EJ, Kuzmina N, Shaikov A, Maximov A, Vorontsov I, et al. Methotrexate in resistant juvenile rheumatoid arthritis. Results of the U.S.A.U.S.S.R. double-blind, placebo-controlled trial. The Pediatric Rheumatology Collaborative Study Group and The Cooperative Children's Study Group. N Engl J Med 1992;326:1043-9.

14. Bowyer SL, Roettcher PA, Higgins GC, Adams B, Myers LK, Wallace C, et al. Health status of patients with juvenile rheumatoid arthritis at 1 and 5 years after diagnosis. J Rheumatol 2003;30:394-400.

15. Gartlehner G, Hansen RA, Jonas BL, Thieda P, Lohr KN. Biologics for the treatment of juvenile idiopathic arthritis: a systematic review and critical analysis of the evidence. Clin Rheumatol 2008;27:67-76.

16. Giannini EH, Ruperto N, Ravelli A, Lovell DJ, Felson DT, Martini A. Preliminary definition of improvement in juvenile arthritis. Arthritis Rheum 1997;40:1202-9.

17. Wallace CA, Ruperto N, Giannini E. Preliminary criteria for clinical remission for select categories of juvenile idiopathic arthritis. J Rheumatol 2004;31:2290-4.

18. Wallace CA, Giannini E, Ruperto N. Optimization of the provisional criteria for clinically inactive disease for select categories of juvenile idiopathic arthritis. Arthritis Rheum 2009;60 Suppl 10:2004. [Abstract] 
19. Prince $F H$, Twilt $M$, ten Cate $R$, van Rossum MA, Armbrust W, Hoppenreijs EP, et al. Long-term followup on effectiveness and safety of etanercept in juvenile idiopathic arthritis: the Dutch national register. Ann Rheum Dis 2009;68:635-41.

20. Eberhard BA, Ilowite NT. Response of systemic onset juvenile rheumatoid arthritis to etanercept: is the glass half full or half empty? J Rheumatol 2005;32:763-5.

21. de Benedetti F, Massa M, Robbioni P, Ravelli A, Burgio GR, Martini A. Correlation of serum interleukin-6 levels with joint involvement and thrombocytosis in systemic juvenile rheumatoid arthritis. Arthritis Rheum 1991; 34:1158-63.

22. Keul R, Heinrich PC, Müller-newen G, Muller K, Woo P. A possible role for soluble IL-6 receptor in the pathogenesis of systemic onset juvenile chronic arthritis. Cytokine 1998;10:729-34

23. Pascual V, Allantaz F, Arce E, Punaro M, Banchereau J. Role of interleukin-1 (IL-1) in the pathogenesis of systemic onset juvenile idiopathic arthritis and clinical response to IL-1 blockade. J Exp Med 2005;201:1479-86.

24. Kutukculer N, Caglayan S, Aydogdu F. Study of proinflammatory (TNF-alpha, IL-1alpha, IL-6) and T-cellderived (IL-2, IL-4) cytokines in plasma and synovial fluid of patients with juvenile chronic arthritis: correlations with clinical and laboratory parameters. Clin Rheumatol 1998;17:288-92.

25. Carrasco R, Smith JA, Lovell D. Biologic agents for the treatment of juvenile rheumatoid arthritis: current status. Paediatr Drugs 2004;6:137-46.

26. Munro JE, Murray KJ. Advances in paediatric rheumatology: beyond NSAIDs and joint replacement. J Paediatr Child Health 2004;40:161-9.

27. Chang J, Girgis L. Clinical use of anti-TNF-alpha biological agents-a guide for GPs. Aust Fam Physician 2007; 36:1035-8.

28. McCann LJ, Woo P. Biologic therapies in juvenile idiopathic arthritis: why and for whom? Acta Reumatol Port 2007;32:15-26.

29. Horneff G, Ebert A, Fitter S, Minden K, Foeldvari I, Kümmerle-Deschner J, et al. Safety and efficacy of once weekly etanercept $0.8 \mathrm{mg} / \mathrm{kg}$ in a multicentre 12 week trial in active polyarticular course juvenile idiopathic arthritis. Rheumatology (Oxford) 2009;48:916-9.

30. Lovell DJ, Giannini EH, Reiff A, Cawkwell GD, Silverman ED, Nocton JJ, et al. Etanercept in children with polyarticular juvenile rheumatoid arthritis. Pediatric Rheumatology Collaborative Study Group. N Engl J Med 2000;342:763-9.

31. Lovell DJ, Reiff A, Jones OY, Schneider R, Nocton J, Stein $\mathrm{LD}$, et al. Long-term safety and efficacy of etanercept in children with polyarticular-course juvenile rheumatoid arthritis. Arthritis Rheum 2006;54:1987-94.

32. Lovell DJ, Reiff A, Ilowite NT, Wallace CA, Chon Y, Lin SL, et al. Safety and efficacy of up to eight years of continuous etanercept therapy in patients with juvenile rheumatoid arthritis. Arthritis Rheum 2008;58:1496-504.
33. Donahue KE, Gartlehner G, Jonas DE, Lux LJ, Thieda $\mathrm{P}$, Jonas BL, et al. Systematic review: comparative effectiveness and harms of disease-modifying medications for rheumatoid arthritis. Ann Intern Med 2008;148:124-34.

34. Lahdenne $\mathrm{P}$, Vähäsalo $\mathrm{P}$, Honkanen V. Infliximab or etanercept in the treatment of children with refractory juvenile idiopathic arthritis: an open label study. Ann Rheum Dis 2003;62:245-7.

35. Gerloni V, Pontikaki I, Gattinara M, Desiati F, Lupi E, Lurati A, et al. Efficacy of repeated intravenous infusions of an anti-tumor necrosis factor alpha monoclonal antibody, infliximab, in persistently active, refractory juvenile idiopathic arthritis: results of an open-label prospective study. Arthritis Rheum 2005; 52:548-53.

36. Horneff G, De Bock F, Foeldvari I, Girschick HJ, Michels $\mathrm{H}$, Moebius D, et al. Safety and efficacy of combination of etanercept and methotrexate compared to treatment with etanercept only in patients with juvenile idiopathic arthritis (JIA): preliminary data from the German JIA Registry. Ann Rheum Dis 2009;68:519-25.

37. Halbig M, Horneff G. Improvement of functional ability in children with juvenile idiopathic arthritis by treatment with etanercept. Rheumatol Int 2009;30:229-38.

38. Nielsen S, Ruperto N, Gerloni V, Simonini G, Cortis E, Lepore L, et al. Preliminary evidence that etanercept may reduce radiographic progression in juvenile idiopathic arthritis. Clin Exp Rheumatol 2008;26:688-92.

39. Simonini G, Giani T, Stagi S, de Martino M, Falcini F. Bone status over $1 \mathrm{yr}$ of etanercept treatment in juvenile idiopathic arthritis. Rheumatology (Oxford) 2005;44:777-80.

40. Prince FH, Twilt $M$, Simon SC, van Rossum MA, Armbrust W, Hoppenreijs EP, et al. When and how to stop etanercept after successful treatment of patients with juvenile idiopathic arthritis. Ann Rheum Dis 2009;68:1228-9.

41. Ruperto N, Lovell DJ, Cuttica R, Wilkinson N, Woo $\mathrm{P}$, Espada $\mathrm{G}$, et al. A randomized, placebo-controlled trial of infliximab plus methotrexate for the treatment of polyarticular-course juvenile rheumatoid arthritis. Arthritis Rheum 2007;56:3096-106.

42. Ruperto N, Lovell DJ, Cuttica R, Woo P, Meiorin $\mathrm{S}$, Wouters $\mathrm{C}$, et al. Long-term efficacy and safety of infliximab plus methotrexate for the treatment of polyarticular-course juvenile rheumatoid arthritis: findings from an open-label treatment extension. Ann Rheum Dis 2010;69:718-22.

43. Tynjälä P, Lindahl P, Honkanen V, Lahdenne P, Kotaniemi $\mathrm{K}$. Infliximab and etanercept in the treatment of chronic uveitis associated with refractory juvenile idiopathic arthritis. Ann Rheum Dis 2007;66:548-50.

44. Richards JC, Tay-Kearney ML, Murray K, Manners P. Infliximab for juvenile idiopathic arthritis-associated uveitis. Clin Experiment Ophthalmol 2005;33:461-8.

45. Rajaraman RT, Kimura Y, Li S, Haines K, Chu DS. Retrospective case review of pediatric patients with uveitis treated with infliximab. Ophthalmology 2006;113:308-14. 
46. Foeldvari I, Nielsen S, Kümmerle-Deschner J, Espada G, Horneff G, Bica B, et al. Tumor necrosis factor-alpha blocker in treatment of juvenile idiopathic arthritisassociated uveitis refractory to second-line agents: results of a multinational survey. J Rheumatol 200734:1146-50.

47. Lovell DJ, Ruperto N, Goodman S, Reiff A, Jung L, Jarosova K, et al. Adalimumab with or without methotrexate in juvenile rheumatoid arthritis. N Engl J Med 2008;359:810-20.

48. Biester S, Deuter C, Michels H, Haefner R, KuemmerleDeschner J, Doycheva D, et al. Adalimumab in the therapy of uveitis in childhood. Br J Ophthalmol 2007;91:319-24.

49. Tynjälä P, Kotaniemi K, Lindahl P, Latva K, Aalto $\mathrm{K}$, Honkanen $\mathrm{V}$, et al. Adalimumab in juvenile idiopathic arthritis-associated chronic anterior uveitis. Rheumatology (Oxford) 2008;47:339-44.

50. Katsicas MM, Russo RA. Use of adalimumab in patients with juvenile idiopathic arthritis refractory to etanercept and/or infliximab. Clin Rheumatol 2009;28:985-8.

51. Favalli EG, Arreghini M, Arnoldi C, Panni B, Marchesoni A, Tosi S, et al. Anti-tumor necrosis factor alpha switching in rheumatoid arthritis and juvenile chronic arthritis. Arthritis Rheum 2004;51:301-2.

52. Gerloni V, Pontikaki I, Gattinara M, Fantini F. Focus on adverse events of tumour necrosis factor alpha blockade in juvenile idiopathic arthritis in an open monocentric long-term prospective study of 163 patients. Ann Rheum Dis 2008;67:1145-52.

53. Humira (adalimumab) [prescribing information]. North Chicago IL: Abbott Laboratories; 2008. http://www. rxabbott.com/pdf/humira.pdf. Accessed July 29, 2008.

54. Crum NF, Lederman ER, Wallace MR. Infections associated with tumor necrosis factor-alpha antagonists. Medicine (Baltimore) 2005;84:291-302.

55. Quartier P, Allantaz F, Cimaz R, Pillet P, Richer O, Desjonqueres $\mathrm{M}$, et al. Efficacy, safety and effect on gene expression profiling of anakinra in systemic-onset juvenile idiopathic arthritis: final results of a randomised, double-blind, placebo-controlled trial (ANAJIS). Pediatric Rheumatology 2008,6(Suppl 1):P27.

56. Reiff A. The use of anakinra in juvenile arthritis. Curr Rheumatol Rep 2005;7:434-40.

57. Ilowite N, Porras O, Reiff A, Rudge S, Punaro M, Martin A, et al. Anakinra in the treatment of polyarticular-course juvenile rheumatoid arthritis: safety and preliminary efficacy results of a randomized multicenter study. Clin Rheumatol 2009;28:129-37.

58. Verbsky JW, White AJ. Effective use of the recombinant interleukin 1 receptor antagonist anakinra in therapy resistant systemic onset juvenile rheumatoid arthritis. J Rheumatol 2004;31:2071-5.

59. Irigoyen PI, Olsen J, Hom C, Ilowite NT. Treatment of systemic juvenile rheumatoid arthritis with anakinra. Arthritis Rheum 2004;50 Suppl:S437.

60. Ohlsson V, Baildam E, Foster H, Jandial S, Pain C, Strike $\mathrm{H}$, et al. Anakinra treatment for systemic onset juvenile idiopathic arthritis (SOJIA). Rheumatology (Oxford) 2008;47:555-6.
61. Lequerré T, Quartier P, Rosellini D, Alaoui F, De Bandt $\mathrm{M}$, Mejjad $\mathrm{O}$, et al. Interleukin-1 receptor antagonist (anakinra) treatment in patients with systemic-onset juvenile idiopathic arthritis or adult onset Still disease: preliminary experience in France. Ann Rheum Dis 2008;67:302-8.

62. Gattorno M, Piccini A, Lasigliè D, Tassi S, Brisca G, Carta $\mathrm{S}$, et al. The pattern of response to anti-interleukin-1 treatment distinguishes two subsets of patients with systemic-onset juvenile idiopathic arthritis. Arthritis Rheum 2008;58:1505-15.

63. Zeft A, Hollister R, LaFleur B, Sampath P, Soep J, McNally B, et al. Anakinra for systemic juvenile arthritis: the Rocky Mountain experience. J Clin Rheumatol 2009; 15:161-4.

64. Woo P. Anakinra treatment for systemic juvenile idiopathic arthritis and adult onset Still disease. Ann Rheum Dis 2008;67:281-2.

65. Kalliolias GD, Liossis SN. The future of the IL-1 receptor antagonist anakinra: from rheumatoid arthritis to adultonset Still's disease and systemic-onset juvenile idiopathic arthritis. Expert Opin Investig Drugs 2008;17:349-59.

66. Weisman $\mathrm{MH}$. What are the risks of biologic therapy in rheumatoid arthritis? An update on safety. J Rheumatol Suppl 2002;65:33-8.

67. Kelly A, Ramanan AV. A case of macrophage activation syndrome successfully treated with anakinra. Nat Clin Pract Rheumatol 2008;4:615-20.

68. Bruck N, Hamel J, Suttorp M, Gahr M, Pessler F. Rapid and sustained remission of macrophage activation syndrome (MAS) associated with systemic-onset juvenile idiopathic arthritis (SoJIA) by treatment with anakinra but without cyclosporine. Arthritis Rheum 2009;60(Suppl 10):234.

69. Lovell DJ, Giannini EH, Kimura Y, Li SC, Hashkes PJ, Reiff AO, et al. Preliminary evidence for sustained bioactivity of IL-1 trap (Rilonacept), a long acting IL-1 inhibitor, in systemic onset juvenile idiopathic arthritis (SJIA). Arthritis Rheum 2007;56:514-5.

70. Lovell DJ, Giannini, EH, Kimura Y, Li SC, Hashkes PJ, Reiff AO, et al. Long-term safety and efficacy of rilonacept in patients with systemic juvenile idiopathic arthritis (SJIA). ACR/ARHP Annual Scientific Meeting, October 17-21, 2009. Pennsylvania: 2009. p. 2053.

71. Church LD, McDermott MF. Canakinumab, a fullyhuman $\mathrm{mAb}$ against IL-1beta for the potential treatment of inflammatory disorders. Curr Opin Mol Ther 2009; 11:81-9.

72. Quartier P, Taupin P, Bourdeaut F, Lemelle I, Pillet P, Bost $M$, et al. Efficacy of etanercept for the treatment of juvenile idiopathic arthritis according to the onset type. Arthritis Rheum 2003;48:1093-101.

73. Yokota S, Miyamae T, Imagawa T, Iwata N, Katakura S, Mori M, et al. Therapeutic efficacy of humanized recombinant anti-interleukin- 6 receptor antibody in children with systemic-onset juvenile idiopathic arthritis. Arthritis Rheum 2005;52:818-25. 
74. Woo P, Wilkinson N, Prieur AM, Southwood T, Leone $\mathrm{V}$, Livermore $\mathrm{P}$, et al. Open label phase II trial of single, ascending doses of MRA in Caucasian children with severe systemic juvenile idiopathic arthritis: proof of principle of the efficacy of IL-6 receptor blockade in this type of arthritis and demonstration of prolonged clinical improvement. Arthritis Res Ther 2005;7:R1281-8.

75. Imagawa T, Mori M, Takei S, Kawano Y, Iwata N, Miyoshi $M$, et al. Efficacy and safety of tocilizumab, an antiIL-6 receptor monoclonal antibody, in patients with polyarticular or oligoarticular onset juvenile idiopathic arthritis. ACR/ARHP Annual Scientific Meeting, November 10- 15, 2006. Washington, DC; 2006

76. Yokota S, Imagawa T, Mori M, Miyamae T, Aihara Y, Takei $\mathrm{S}$, et al. Efficacy and safety of tocilizumab in patients with systemic-onset juvenile idiopathic arthritis: a randomised, double-blind, placebo-controlled, withdrawal phase III trial. Lancet 2008;371:998-1006.

77. De Benedetti F. Targeting interleukin-6 in pediatric rheumatic diseases. Curr Opin Rheumatol 2009;21:533-7.

78. Nakajima S, Naruto T, Miyamae T, Imagawa T, Mori $\mathrm{M}$, Nishimaki $\mathrm{S}$, et al. Improvement of reduced serum cartilage oligomeric matrix protein levels in systemic juvenile idiopathic arthritis patients treated with the antiinterleukin-6 receptor monoclonal antibody tocilizumab. Mod Rheumatol 2009;19:42-6.

79. Ruperto N, Lovell DJ, Quartier P, Paz E, Rubio-Pérez $\mathrm{N}$, Silva CA, et al. Abatacept in children with juvenile idiopathic arthritis: a randomised, double-blind, placebocontrolled withdrawal trial. Lancet 2008;372:383-91.

80. Angeles-Han S, Flynn T, Lehman T. Abatacept for refractory juvenile idiopathic arthritis-associated uveitisa case report. J Rheumatol 2008;35:1897-8.

81. Emery P, Fleischmann R, Filipowicz-Sosnowska A, Schechtman J, Szczepanski L, Kavanaugh A, et al. The efficacy and safety of rituximab in patients with active rheumatoid arthritis despite methotrexate treatment: results of a phase IIB randomized, double-blind, placebocontrolled, dose-ranging trial. Arthritis Rheum 2006; 54:1390-400.

82. Edwards JC, Szczepanski L, Szechinski J, FilipowiczSosnowska A, Emery P, Close DR, et al. Efficacy of B-cell-targeted therapy with rituximab in patients with rheumatoid arthritis. N Engl J Med 2004;350:2572-81.
83. El-Hallak M, Binstadt BA, Leichtner AM, Bennett CM, Neufeld EJ, Fuhlbrigge RC, et al. Clinical effects and safety of rituximab for treatment of refractory pediatric autoimmune diseases. J Pediatr 2007;150:376-82.

84. Kuek A, Hazleman BL, Gaston JH, Ostör AJ. Successful treatment of refractory polyarticular juvenile idiopathic arthritis with rituximab. Rheumatology (Oxford) 2006;45:1448-9.

85. Kasher-Meron M, Uziel Y, Amital H. Successful treatment with B-cell depleting therapy for refractory systemic onset juvenile idiopathic arthritis: a case report. Rheumatology (Oxford) 2009;48:445-6.

86. Alexeyeva EI, Bzarova TM, Valiyeva SI, Isayeva KB, Chomakhidze AM, Akulova SS, et al. Efficacy and safety of rituximab in patients with juvenile idiopathic arthritis. Acta-Paediatr 2008;97(Suppl 459):P71.

87. Lehman TJ, Schechter SJ, Sundel RP, Oliveira SK, Huttenlocher A, Onel KB. Thalidomide for severe systemic onset juvenile rheumatoid arthritis: A multicenter study. J Pediatr 2004;145:856-7.

88. García-Carrasco M, Fuentes-Alexandro S, Escárcega RO, Rojas-Rodriguez J, Escobar LE. Efficacy of thalidomide in systemic onset juvenile rheumatoid arthritis. Joint Bone Spine 2007;74:500-3.

89. Cohen S, Cannon GW, Schiff M, Weaver A, Fox R, Olsen $\mathrm{N}$, et al. Two-year, blinded, randomized, controlled trial of treatment of active rheumatoid arthritis with leflunomide compared with methotrexate. Utilization of Leflunomide in the Treatment of Rheumatoid Arthritis Trial Investigator Group. Arthritis Rheum 2001;44:1984-92.

90. Silverman E, Mouy R, Spiegel L, Jung LK, Saurenmann RK, Lahdenne P, et al. Leflunomide or methotrexate for juvenile rheumatoid arthritis. N Engl J Med 2005; 352:1655-66.

91. De Kleer IM, Brinkman DM, Ferster A, Abinun M, Quartier P, Van Der Net J, et al. Autologous stem cell transplantation for refractory juvenile idiopathic arthritis: analysis of clinical effects, mortality, and transplant related morbidity. Ann Rheum Dis 2004;63:1318-26.

92. Brinkman DM, de Kleer IM, ten Cate R, van Rossum MA, Bekkering WP, Fasth A, et al. Autologous stem cell transplantation in children with severe progressive systemic or polyarticular juvenile idiopathic arthritis: long-term follow-up of a prospective clinical trial. Arthritis Rheum 2007;56:2410-21. 